This item was submitted to Loughborough's Research Repository by the author.

Items in Figshare are protected by copyright, with all rights reserved, unless otherwise indicated.

\title{
Limits of interest empowerment in the European Union: The case of football
}

PLEASE CITE THE PUBLISHED VERSION

http://dx.doi.org/10.1080/07036337.2011.611400

\section{PUBLISHER}

Rouledge (๑ Taylor and Francis)

VERSION

AM (Accepted Manuscript)

\section{LICENCE}

CC BY-NC-ND 4.0

\section{REPOSITORY RECORD}

Garcia, Borja, and Henk-Erik Meier. 2019. "Limits of Interest Empowerment in the European Union: The Case of Football”. figshare. https://hdl.handle.net/2134/8918. 
This item was submitted to Loughborough's Institutional Repository (https://dspace.lboro.ac.uk/) by the author and is made available under the following Creative Commons Licence conditions.

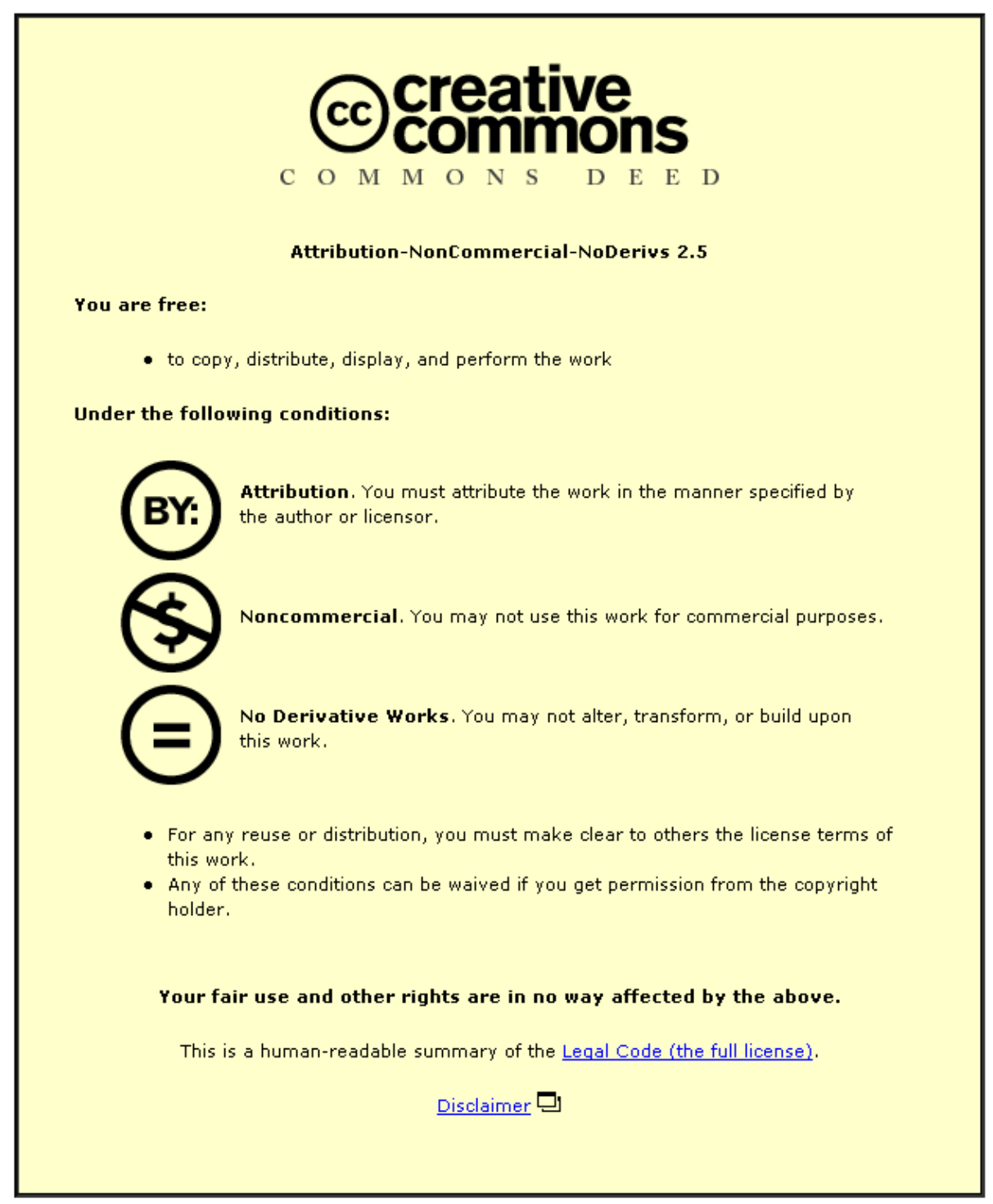

For the full text of this licence, please go to: http://creativecommons.org/licenses/by-nc-nd/2.5/ 


\title{
Limits of interest empowerment in the European Union: The case of football
}

Borja García (Loughborough University)

Henk-Erik Meier (University of Munster)

\begin{abstract}
The European Union (EU) represents an emerging opportunity structure refining societal actors' chances to get access to and influence over policy-making. While research has mainly focused on lobbying within the legislative arena we provide evidence that competition policy can also be understood as a venue of interest group politics by taking the case of European football. The specific institutional features of competition policy have the potential to increase probability of access and lower costs for political action for certain interest groups but also to limit potential benefits from interest group politics. Professional football players and clubs in Europe have used competition policy procedures as an avenue to challenge the supremacy of governing bodies such as UEFA in the game's organisational structures. Whilst managing some impact in terms of policy, the challengers have attained only moderate influence in football’s sectoral governance.
\end{abstract}

Keywords: competition policy; empowerment; European Union; football; lobbying 


\section{Introduction}

The European Union (EU) represents an emerging political opportunity structure offering some actors additional resources for exerting influence, while constraining the options of others(Marks \& McAdam 1999). European football represents an exemplary case for studying how the policies of the EU have the potentially to disturb existing power relationships and power equilibria between incumbent actors in other systems.

The EU incursions in sport have been labelled as ‘indirect sports policy’ (Tokarski et al. 2004, p.55) representing an incremental accumulation of legal cases whereby the extent of the application of competition policy and the single market regulations to sport were considered (Parrish 2003; Dimitrakopoulos 2006; García 2007, 2009; Meier 2009). In the Lisbon Treaty however, the European Union has been equipped, for the first time, with a direct competence on sport, albeit only to 'to support, coordinate or supplement the actions of the Member States' (see Articles 6 and 165 of the treaty on the Functioning of the European Union) (C306/06, Official Journal, 17-12-07, p.1),, which is the lowest level of competences attributed to the EU (see Weatherill 2010, García \& Weatherill 2012). Whereas a 'direct’ sport policy by the EU is still in its infancy (Tokarski et al. 2004, García \& Weatherill 2012, the impact of Article 165 on EU sports policy remains to be seen at this moment, but early legal and political analysis suggests that criteria for the application of EU competition law (which is of special interest in this article) are unlikely to be changed and, therefore, those aspects of EU sports policy will probably not suffer major modifications (Parrish et al. 2010).

Thus, EU sport policy, especially pre-Lisbon, features a significant number of cases where regulations adopted by football governing bodies have been challenged by stakeholders such as clubs or players before the European courts or the Commission. Among these cases, the Bosman ruling is probably best known because a marginalised player succeeded in contesting the power of the football bodies to restrict player mobility. 
In order to understand EU induced power shifts within European football, it is essential to take into account that the power of governing bodies in football originates in the governance structures of the game. Traditionally, football has been organised along a pyramid, with FIFA, world football's governing body at the apex. FIFA is then followed by the continental confederations, UEFA in the case of Europe, the national football associations and the national professional football leagues. Finally, clubs and players were firmly situated at the bottom of the pyramid (Tomlinson 1983, p.173). This was not just a vertical structure, but also a hierarchical one. The statutes of the governing bodies ensure that rules and regulations adopted at their level are filtered down the pyramid and abided by those stakeholders in the lower echelons. Thus, the governing bodies (FIFA, UEFA and national FAs) had preponderance in the governance of the game due to the vertical channels of authority that run from the top to the bottom. Their central role within sport governance allowed the sport to adopt monopoly practices that could, allegedly, violate EU competition law.

In the European context, those vertical channels of authority have been weakened to some extent and they are in the process of being replaced by a horizontal structure of network governance (García 2007, Holt 2007). It is generally accepted that professional clubs and players have abandoned their marginal position in the bottom of the pyramid following the Bosman case and European Commission investigations into the selling of football broadcasting rights (see Holt, 2006). Nevertheless, the relative empowerment of players and clubs is open to discussion. Regardless of substantial policy shifts favouring clubs and players, decision making bodies (executive committee and congress) at both FIFA and UEFA are still to incorporate representatives from the clubs and players. UEFA has institutionalised consultation with both stakeholders through the Professional Football Strategy Council (García 2009). FIFA accepted the participation of the players' trade union (FIFPro) in its Dispute Resolution Chamber dealing with contractual disputes between players and clubs 
(FIFPro 2001). However, in terms of potential alternative forms of sport governance, these changes appear only to be moderate. Instead of forming their own closed professional European competition, G-14, the lobby group representing 18 European top clubs, has even decided to resolve in 2008. Professional players faced also difficulties to exploit particular favourable conditions for transnational unionism in football (Dabscheck 2003; Parrish 2011).

Given the opportunity of an institutional takeover of professional clubs and players, we address this puzzle: Why a relatively modest institutional change in the professional football sector in Europe despite the fact that EU involvement in sport came with potential for power shifts? We argue that one possible explanation for this lies in the specific features of competition policy as the institutional arena that empowered formerly marginalised actors in football.. EU competition policy has the potential to modify the political opportunity structure in a way that it increases access probabilities and lowers cost of political action for some actors considerably. However, competition policy venue constrains potential benefits of interest group activity and does not guarantee that empowerment effects can be transferred to other venues. The article presents evidence from two cases where players and clubs challenged the hegemony of UEFA and FIFA. We claim that the case of European football provides interesting insights for researchers interested in the general dynamics of EU interest group politics

\section{EU interest group empowerment in non-majoritarian arenas}

Research on EU interest representation has made progress in mapping societal actors' access to the European policy-making process (Woll 2006; Coen 2007), but it has mainly focused on lobbying within the legislative arena (Princen \& Kerremans 2008). Although - as football cleary demonstrates (Parrish 2011) - the judicial activism of the European Court of Justice (ECJ) could inspire interest groups to prefer litigation over lobbying (Coen 2007), only few scholars have studied such litigation strategies (Bouwen \& McCown 2007). 
Here, we aim at broadening the analysis by focusing on a so-called non-majoritarian political arena, that is, competition policy. Non-majoritarian political arenas are detached from traditional chains of democratic delegation and oversight since executive actors are granted statutory authority to perform functions of policy formation and implementation within a broad range of discretion. Such non-majoritarian arenas are quite characteristic for the EU, because the Commission is in control of policy-formation and implementation in a number of policy domains (Majone 1997). Therefore, we aim to analyse competition policy as a nonmajoritarian arena of interest group politics.

Conceptually, it is important to distinguish between two different processes in the application of European competition law, that is, public enforcement and private litigation. Public enforcement of the Treaty's competition policy provisions refers to the powers conferred to the European Commission's Directorate General for Competition Policy to investigate whether undertakings' practices comply with Articles 101 et seq. of the TFEU. Public enforcement led by the European Commision fits perfectly into the image of non-majoritarian policy-making. The Commission enjoys a particular strong role in designing and enforcing policy and can heavily influence policy through individual decisions since the Commission can impose fines and require undertakings to modify their practices. Moreover, as suited vehicle to facilitate market integration, competition policy within the EU possesses characteristics of a horizontal 'meta-policy'. Thus, the Commission has developed competition policy into one of the most centralised and powerful EU competences, which is only subject to review by the EU courts (Wilks 2005; Wilks \& Bartle 2002).

Interest groups can also rely on private litigation based on competition policy before national courts, which may then refer the issue at stake for a preliminary ruling to the Court of Justice of the EU or not As Parrish (2011) argues, football stakeholders have successfully challenged governing bodies' rules and regulations in courts. This venue is relatively easy to enter, 
except for the need of legal expertise and litigation costs. Since it invests all the power of decision on the courts, private litigation is even more of non-majoritarian character than public enforcement, which can become highly politicised. Additionally, the opportunity to rely on private enforcement can increase sectoral bargaining power.

Whereas our analytical focus is primarily on public enforcement, our two case studies feature both public enforcement and private litigation. The investigation into the selling of Champions League marketing rights, conducted by the Commission, is an instance of the public enforcement of competition policy. The case of FIFA's international transfer system is slightly more nuanced, though, for it originated on the Bosman case as a prime example of private litigation against football governing bodies based on freedom of movement provisions. The follow up by the European Commission to investigate FIFA's international transfer system, a couple of years after the judgment, was based on competition policy provisions, though, and it consequently was affected by its institutional characteristics. Thus, the Bosman case illustrates how public and private enforcement of competition policy are interlinked. The Bosman ruling enabled aggrieved actors to contest the power of the sport bodies by relying on private enforcement of competition law. The significant change in the political opportunity structure by Bosman is indicated by an immediate influx of up to fifty sport-related complaints and questions to the Commission (Pons 2002, p.244). Furthermore, by criticising the Commission's hesitant stance, the ECJ called for a more decisive public enforcement of EC competition law in the sport domain (Weatherill 2003, García 2007a).

TThe powerful role of the Commission within competition policy comes with strong implications for the political opportunity structure defined as institutional features that determine the relative ability of interest groups to influence decision making within a political arena. The concept comprises two dimenssions: A structural aspect relating to the openness of 
a political system and the ease of access and, the receptivity of the political system to the claims of certain political actors (Princen \& Kerremans 2008, p.1131).

For the sake of parsimony, we follow Down's (1957) classic assumption that the utility of political action can be represented in the following cost-benefit calculus:

$U=P \times B-C$,

where $U$ refers to the utility of political action in a certain institutional venue, $P$ to the probability of interest group success, and $B$ to benefits from an interest group's success. Finally, $C$ denotes the costs of political action. The specific political opportunity structure within competition policy heavily affects that calculus so that competition policy might appear to interest groups as an attractive venue for attaining policy change.

Here, we explore how institutional features of competition policy affect the expected utility from interest group activity within that arena $\left(U_{\text {Comp }}\right)$ in comparison with political actions in alternative (majoritarian) venues of sport policy $\left(U_{A l t}\right)$, where traditionally the sport bodies dominate. Thus, we present a theoretical claim about the relative advantages that actors contesting the sport bodies' power enjoy within competition policy compared to other arenas. We do not claim that actors challenging the power of sport bodies will automatically achieve their objectives by relying on public or private enforcement of competition law. Rather we argue that competition policy provides better prospects to achieve at least some political aims than other venues.

Concerning public enforcement of competition law, the Commission is first of all mainly interested in the liberalisation of the focal sector, which results in a bias towards certain policy solutions and a narrow issue definition that comes with implications for the benefits to be derived from interest group activity $(B)$ as well as for access and success probabilities $(P)$. Narrow issue definition comes with an ambiguous effect: It restricts policy issues to questions 
of liberalisation but works also against dominant players claiming to pursue a more 'holistic view'. In terms of benefits, the liberalisation of a particular sector would be in the interest of formerly marginal actors (i.e. outsiders) as liberalisation might result in the re-distribution of resources (be that market share, capital) in their favour. Yet, the biggest benefits for these marginal outsiders do not arise only from economic liberalisation - resulting in a bigger share of the economic rents - but from a substantial shift in sectoral governance, that might allow those marginal actors to increase their power within the sector and their control of those very economic revenue streams. For example, player market liberalisation results almost inevitably in salary increases but encompassing CBAs can enable player unions to also improve social security while maintaining economic viability of team sport industries. In a comparable manner, clubs would be economically better off if they would be in complete control of the professional game. Narrow issue definition can further restrict benefits from interest group activity by precluding issue-linkages between policy dimensions (Tsebelis 2002). Therefore, potential benefits from political action within the competition policy arena are lower than from alternative courses of interest group politics $\left(B_{\text {Comp }}<B_{A l t}\right)$ :

Proposition \#1: Narrow issue definition within the competition policy arena can limit the foreseeable benefits from interest group activity by restricting the set of policy solutions and by making more-dimensional political exchanges more difficult.

Competition policy can also heavily affect the probability of interest group access and success $(P)$ because the strong procedural powers of the Commission increase the probability that interest groups supporting the Commission's policy aims will be granted access and policy influence. Interest group activity outside competition policy is likely to meet less favourable conditions in particular when interest groups aim to challenge the dominant role of incumbent interests supported by other actors such as the Member States. Thus, interest groups intending to contest incumbents' dominant role enjoy a strategic advantage within the competition 
policy arena $\left(P_{\text {Comp }}>P_{A l t}\right)$ if they can align their preferences with the Commission's liberalising policy:

Proposition \#2: Within competition policy, interest groups likely to contribute to the achievement of Commission's liberalising policy aims will experience higher probabilities of access and success.

Thus, if the Commission uses competition policy to address market barriers deeply entrenched in other policy arenas, the Commission can increase the probability of success for actors formerly marginalised in those venues. Here, narrow issue definition works in favour of the challengers since European competition policy tends to disadvantage actors with a more 'holistic' view and to ignore normative concerns alien to competition policy (Wilks 2005). Therefore, interest groups with a narrow mandate and constituency enjoy higher probabilities of access and influence than broader and more encompassing interest groups. Moreover, proposition \#2 implies that 'political money' within competition policy consists not only of information but of veto-power since interest groups able to legitimise certain policy solutions are of utmost interest for the Commission. Interest groups qualifying as claimants in competition law proceedings will have higher probabilities of access because they represent 'partisan veto players’ (Tsebelis 2002), which also implies that access is more directly linked to actual influence on policy-making.

The fact that partisan veto player status is decisive has consequences for the costs of interest group activity. We assume that relying on veto player status in order to achieve political aims is probably less costly than bearing the costs for lengthy political action outside competition policy which include, among others, costs for campaigning for grassroot support, lobbying in several arenas and meeting counter efforts by incumbent players (Rubin et al. 2001). 
Therefore, we hypothesize that cost of action within competition policy arena is lower in comparison to other EU political arenas $\left(C_{\text {Comp }}<C_{\text {Alt }}\right)$ :

Proposition \#3: Empowerment within the arena of competition policy bears the potential to considerably lower the costs for collective action by turning interest groups into partisan veto players.

In sum, public enforcement of competition policy features a relatively attractive combination of success probabilities and low costs that can increase its expected utility for certain interest groups, in particular, when interest groups can align their policy preferences with the liberalising agenda of DG Comp and when they can become veto players through claimant status. In those cases, the expected utility from alternative political action can be lower than from interest group activity within competition policy $\left(U_{\text {Comp }}>U_{A l t}\right)$.

In contrast, competition policy has the potential to limit feasible benefits from interest group activity due to narrow issue definition. Interest group activity outside the arena of competition policy promises greater benefits due to the opportunity to achieve institutional change or to engage in more encompassing bargaining. However, we expect that it is not easy for interest groups to transfer empowerment effects from competition policy:

Proposition \#4: Regardless of empowerment by competition policy, interest groups might remain unable to pursue their aims more effectively on other political venues, if they continue a 'low cost' strategy

Thus, the difficult transfer of empowerment effects could explain the relatively moderate change in football's sectoral governance. However, a general caveat has to be made. The discretion the Commission enjoys is never unlimited and legal issues within the EU can always provoke intense Member State involvement (Princen \& Rhinard 2006). Even 
European competition policy can become highly politicised (Wilks 2005), propelling a relatively 'low politics' competition policy dossier to the 'high politics' category; hence altering the narrow legal definition of the issue at stake. Thus, we have to theorise:

Proposition \#5: Benefits from competition policy for interest groups pursuing a liberalisation agenda in accordance with the Commission might be limited in case the Commission’s policy ambitions are met with strong Member States' resistance and the issue at stake becomes highly politicised.

\section{Challenging football governance in the competition policy venue}

Although we cannot 'test' all of our propositions by conducting case study evidence, we present 'heuristic' case studies to infer and to construct a causal chain account of how various conditions and variables interacted to produce a certain policy outcome. We examine two competition policy cases particularly consequential for European football governance. These cases concern, first, the Commission investigation on the selling of broadcasting rights for the UEFA Champions League (CL) that saw UEFA's legitimacy being challenged by top professional clubs; and second, the Commission investigation into the transformation of the international transfer system, where the players union (FIFPro) was involved attempting to modify FIFA regulations .

\section{Selling of CL broadcasting rights}

Sport broadcasting poses serious challenges for antitrust authorities because many professional leagues have implemented collective selling systems as a vehicle for revenue redistribution among participating teams. Although the efficacy of such redistribution schemes is doubted, they are deemed necessary to maintain balanced competitions (Meier 2005). In Europe, football governing bodies used to control these collective selling systems 
and to act as monopoly suppliers. That monopoly of political and economic power was increasingly challenged by the professional clubs, who wanted a larger share of the revenues.

When UEFA decided to transform the old European Cup, one of the key foundations of the new Champions League was the central selling of the competition's commercial rights by UEFA on behalf of the participating clubs (UEFA 2001, p.2). UEFA notified the Commission on 19 February 1999 requesting clearance that the selling arrangements for CL broadcasting rights complied with competition law (European Commission 2003, para.18). UEFA argued that it would not organise the CL without joint selling and being able to redistribute the revenues among the 'football family' (European Commission 2003, para. 130). UEFA's arrangements assume that the governing body is the owner of the rights (UEFA 2007, articles 27-28) and, therefore, it can market them centrally. However, this practice might, prima facie, restrict competition given UEFA’s monopoly.

Therefore, the Commission could decide not to endorse UEFA's proposal, requesting that broadcasting rights are sold individually by the participating clubs, which would have induced supply side competition. Politically, these competition policy proceedings had far-reaching implications for football governance by either maintaining UEFA's power over the clubs or by giving the clubs a much more prominent stake in football governance.

The anti-competitive effects of UEFA's proposed selling arrangements were highlighted when DG Comp issued a statement of objections on 18 July 2001, which informed UEFA that their selling arrangements were not eligible for an exemption under Article 101 (3) TFEU (European Commission 2003, para.18). Instead, the Commission wanted to increase supply side competition and to reduce exclusivity of rights, so that more games would be broadcasted and more broadcasters per market could purchase the CL broadcasting rights (European Commission 2001a, 2001b). 
Given the Commission's liberalising agenda, the top professional clubs could become almost natural allies, because individual selling would earn the clubs much more revenues whilst, at the same time, it would have induced more supply side competition. In November 2001 UEFA presented revised arrangements for the selling of broadcasting rights where supply was substantially improved to avoid anticompetitive consequences (European Commission 2003, para.23). The Commission announced that, in principle, it could look favourably to UEFA's proposal, subject to giving third parties the opportunity to comment on the arrangements (European Commission 2002, p.1). This was the key moment when G-14, as a representative of top professional football clubs, was invited to join the proceedings expressing whether it had objections on the revised UEFA proposal.

The Commission empowered the top clubs by creating a climate of legal uncertainty and by challenging the policies of UEFA that had remained uncontested for a long time. While DG Comp was procedurally required to invite third parties comments on the proceedings, involving G-14 enabled DG Comp not only to investigate the exclusivity of broadcasting rights (i.e. ensuring more TV operators can offer CL matches to the final consumer), but also to tackle supply side competition (i.e. a higher number of matches for the TV operators to broadcast) because G-14 could litigate against UEFA on the base of rights’ ownership claims. Tackling exclusivity and supply at the same time, the liberalising effect would be, therefore, multiplied. Crucially, without involving the clubs DG Comp could not decide questions of rights ownership because the proceedings were formally a clearance request filed by UEFA (Van den Brink 2000).

In response to DG Comp's invitation, G-14 requested for the clubs the right to exploit secondary and minor rights, a stronger say in the marketing of CL sponsoring, and a reduction in exclusivity in order to control sublicensing deals and to increase revenues from so-far unused new media rights (European Commission 2003, para. 90-93). However, due to media 
market recession, G-14 was afraid that substantial institutional change would destabilise European club football (Bossmann 2001).

UEFA's strategy during the proceedings was twofold. On the one hand it engaged in negotiations with DG Comp to devise suitable selling arrangements that could be exempt:

We had lots of meetings; many of them were very long and normally well spirited. We met every day, literally every day and always with lots of dialogue. Yes, we had different positions, but it was not dogmatic, we rather tried to find solutions (Interview, former UEFA senior executive, February 2007)

On the other hand, UEFA tried to lobby on national governments through national FAs. UEFA requested its national associations to contact national leaders and it even sent the FAs sample letters to be used for that purpose (Interview, senior director, The English FA, April 2006). However, politicisation failed and national governments did not decisively support UEFA . The Member States' interest in stimulating new media markets was at odds with UEFA's practice of granting exclusive contracts to single broadcasters as the Commission stressed (Pons, 1999; Ungerer, 1999). Thus, even though the Member States were sympathetic to governing bodies' arguments that further intervention by the ECJ or the Commission in sport could endanger the so-called European model of sport (García 2007a), the European Council only explained in the non-binding (soft law) Nice Declaration on Sport of 2000, 'that moves to encourage the mutualisation of part of the revenue from such sales, at the appropriate levels, are beneficial to the principle of solidarity between all levels and areas of sport' (European Council 2000, p.2).

The proceedings were settled informally between UEFA and the Commission following some further amendments to the arrangement devised by UEFA (European Commission 2002a, 2003). The Commission granted a three-year exemption to the revised arrangements for the 
selling of CL broadcasting rights proposed by UEFA. The governing body had to modify its initial policy of central selling and long exclusive contracts. UEFA was allowed to sell part of the broadcasting rights but it was forced to divide its commercial rights into fourteen smaller packages, to be sold on a country by country basis for a period not exceeding three years (European Commission 2002a, p.1). In terms of ownership of rights, the Commission opted for an equitable decision whereby both UEFA and the participating clubs where considered co-owners of the CL commercial rights (European Commission 2003, para. 32-40). UEFA retained the exclusive right to sell the most attractive live rights packages, but other rights packages are co-exploited by both UEFA and the participating clubs (European Commission 2003, para. 32-54; UEFA 2002).

In sum, the antitrust proceeding enabled the top clubs to contest the rule of UEFA and push for a bigger share of the revenues generated within the European football industry. Whereas due to the economic risks of institutional change, G-14 pursued a risk-averse strategy, the top clubs succeeded forcing UEFA to accept some institutional change since club co-ownership of broadcasting rights was established.

\section{The regulation of the players market}

Player market regulation represents a highly sensitive issue because of the perceived links between transfer payments, solidarity and training efforts in grassroots football. The football bodies implemented restrictions of player mobility to facilitate competitive balance and to subsidy training efforts by small grassroots clubs. Scholars have doubted both effects and stressed that mobility restrictions inevitably result in player exploitation (Moorhouse 1999).

In Bosman, the ECJ abolished the so-called nationality quotas and the FIFA international transfer system in place at that moment, which required transfer payments for players even after the end of their contract. Thus, footballers could not change employers unless a club was 
willing to pay an agreed transfer fee. Following Bosman nationality quotas were quickly abolished after a meeting of the UEFA executive committee in February 1996 (Goodbody 1996), but the transfer regulations were subject to a more lengthy debate and a European Commission investigation.

FIFA and UEFA initially informed the Commission that the international transfer system would no longer apply to players who changed clubs at the end of their contracts to play in a different country within the European Economic Area, but the rules were not officially revoked. Therefore, the Commission opened an infringement procedure against FIFA in December 1998 (Reding 2000, European Commission 2002b, p.1). With this decision the Commission brought the issue to the area of public enforcement of competition policy.

Initially the Commission aimed at a substantial policy shift in terms of the transfer system, albeit within a narrow liberalisation remit. DG Comp demanded restrictions of contract duration, unilateral right for contract termination and non-discretionary compensation payments for premature breach of contract (Parrish 2003, p.140-142). For the Commission, the player unions had to be the natural ally because the players were going to be the big winners of any further player market liberalisation.

Before Bosman, FIFPro had failed to convince the football bodies to lift mobility restrictions on players. This time, the Commission's attack on the transfer system represented a significant opportunity for FIFPro. The Commission requested the governing bodies to present amendments to the challenged transfer system that could be acceptable not just in legal terms, but also for all affected stakeholders; any reform of the transfer system had to be at least acceptable for the players (European Commission 2000, p.2). Thus, FIFPro was initially granted veto player status and given the opportunity to shape any amendments to the international transfer system. The clubs were also granted a say by the Commission but they 
opposed the liberalisation agenda because players are major business assets (Welch \& Gardiner 2007). G-14 feared that economic interests would be compromised in the negotiations about a new transfer system.

In the debates between FIFA, UEFA, G-14 and FIFPro, insurmountable conflicts between the latter two resulted in bargaining deadlock. As a consequence, FIFPro and G-14 were marginalised from the final stages of the negotiations with the Commission (Bose 2000). FIFPro was bypassed by an agreement between UEFA, FIFA and the Commission (European Commission 2001c). FIFPro proved paralysed by an internal clash between a faction fond of a complete deregulation of the player market and a more pragmatic faction intending to 'trade' some mobility restrictions for better social security (Dabscheck 2003). Since the narrow issue definition of player market regulation within competition policy did not allow broadening the issue towards more encompassing collective bargaining, FIFPro was not able to solve that internal conflict, which contributed to FIFPro’s walk-out (Bose 2000; Meier 2005). FIFPro’s lack of strategic capacity was compensated by DG Comp's insistence on liberalising the players market and, moreover, the football bodies' concerns about further FIFPro litigation (Dimitrakopoulos, 2006).

It is not necessary to recall all stipulations of the new transfer system. In essence, the settlement with the Commission required the football bodies to substantially liberalise the player market by restricting maximum duration of player contracts. However, the football bodies' main concerns were insofar respected as the transfer agreement legitimised training compensation fees for transfers of young players and solidarity mechanisms benefitting the clubs involved in the training and education of football players. The settlement has been interpreted as a compromise between the initial positions of FIFA and the Commission, although it has been considered as beneficial for the governing bodies (Parrish 2003, p.147). 
This is due to a substantial politicisation of the transfer system issue by the Member States, which had strong preferences for subsidising training efforts of grassroots football (Dimitrakopoulos 2006). At several occasions, the Member States signalled the Commission that they expected more concessions towards the football bodies. In September 2000, British PM and the German Chancellor demanded a cooperative solution paying regard to all stakeholders (Prime Minister's Office 2000, 2001). In December 2000, the Member States’ Nice Declaration on Sport supported again a cooperative solution of the player market issue (European Council 2000). Eventually, the Swedish Presidency of 2001 facilitated an informal settlement (European Commission 2001e).

Thus, Member States' intervention served to mitigate the liberalising agenda of the Commission and to broaden the initial narrow issue definition towards a more 'holistic' view on sport governance and the specificity of sport - but not towards collective bargaining. Therefore, narrow issue definition is a characteristic of the public enforcement of competition policy but it also has limits. The multi-institutional nature of the EU limits the executive's powers and political pressure from the Member States, as theorised above, can re-define the issue at stake. For external actors, this is more likely to happen when their discourse and policy preference can be aligned with the Member States', hence facilitating high politics status.

Nevertheless, the deregulatory nature of the transfer agreement makes evident that FIFPro benefitted to a certain extent from the compromise despite its walk-out. Although Member State intervention did not aim to expand the initial narrow issue definition towards more encompassing collective bargaining, FIFPro was certainly better off with the compromise in particular when FIFPro's previous poor record in negotiations with the football bodies is considered (Meier, 2005). While G-14 had finally to accept substantial liberalisation, it got de 
facto acknowledged as an employer representative signalling that G-14 was able to challenge player market regulations unilaterally adopted by the football bodies.

\section{Discussion: Interest group failure in alternative venues}

As shown, G-14 and FIFPro benefitted from public enforcement of competition policy in terms of policy shifts and some institutional change. Public enforcement challenged rules of FIFA and UEFA that no football stakeholder had managed to dispute, even if they had been trying for two decades because the traditional governance of football ensured the primacy of the put the governing bodies. Therefore, the opportunity opened by the Commission was groundbreaking for football governance standards. We now explore the extent to which FIFPro and G-14 were able to further capitalise on the opportunities opened by the Commission investigations.

\section{G-14: Failure of capacity building and demise}

The record of G-14 supports our claim that interest groups face problems transferring empowerment effects from public enforcement of competition policy into other venues where political action is more costly. G-14 failed to build the organisational capacities and legitimacy necessary to take on more responsibility within football governance.

First, increasing legitimacy among football stakeholders and assuming a regulatory role required more investments than relying on competition policy. Second, there were additional factors debilitating G-14, especially the group’s own heterogeneity and the stark opposition from UEFA and FIFA, who never recognised G-14 as legitimate stakeholder (Holt 2006, p.96; see also UEFA 2008).

G-14's attempt to broaden its support by establishing an annual international club conference including representatives from outside the group was countered by UEFA's creation of the European Club Forum (ECF) in 2002 (Grant 2009). The ECF was intended as a forum for 
consultations with Europe's major professional clubs within the UEFA structures. Since top clubs from all 53 Member Associations were considered, UEFA claimed that the ECF was more representative and democratic than G-14 (Holt 2006, p.96-97). That move indicated that UEFA had to accept professional clubs as legitimate stakeholders due to EU induced power shifts but was not willing to recognise G-14 itself. The group’s confrontational strategy made UEFA and FIFA perceive G-14 as a real threat to their own powers (Holt 2006; Interview, UEFA former General Secretary, February 2007).

Moreover, G-14 was unable to deal with internal heterogeneity. In 2001, G-14 members could not agree to block a reform of the CL format proposed by UEFA because G-14 clubs benefitted very unequally from CL matches and had different opinions about an overcrowded match calendar (Banks 2002, p.129-35). In 2002, G-14 announced it intended to implement a 'soft salary cap’ from 2005 on in order to impose some financial discipline on its members . However, it proved impossible to implement because some G-14 clubs pursue profit aims and others purely sporting aims (Moorhouse 2007). In a similar manner, G-14 could not find a common position when UEFA presented in 2006 its home grown players rules for European club competitions (see García 2007b, p.213-217). G-14’s inaction enabled UEFA to adopt the home grown rules virtually unopposed.

It is interesting to note, that clubs only real success against the governing bodies was achieved when they resorted to the threat of private enforcement of competition law before national courts. The clubs had long objected the football bodies’ policy of mandatory player release for national team duty. The Oulmers case allowed the clubs to claim that these FIFA's rules represented an abuse of a dominant position by the governing bodies resulting in a disenfranchisement of players as one of the clubs' most important business assets (Parrish \& Miettinen 2008, p 224). In the Oulmers case, the Moroccan international player Abdelmajid Oulmers returned injured to his club (Charleroi) from national team duty in 2004 without the 
club getting compensated. Initially Charleroi started legal proceedings before a Belgian national court to obtain compensation. Charleroi claimed that FIFA's rules on the release of players for national team duty were in breach of competition policy provisions. G-14 joined the litigation, which was referred to the ECJ for a preliminary ruling (SA Sporting du Pays de Charleroi and G-14 Groupment des clubs de football européens v. Fédération internationale de football association (FIFA), case C-243/06, Official Journal, 02-09-06, C 212, p.11).

Facing a possible upset by the Court, FIFA and UEFA decided to negotiate an out of court settlement. They agreed to increased compensation payments to clubs and an insurance scheme for the release of players for the final rounds of the European Championships and the FIFA World Cup (UEFA 2008). In exchange, G-14, which had failed to build governance capacity, agreed to cease its operations and to withdraw the legal challenge (G-14 2008). UEFA then dissolved the ECF and recognised the European Club Association (ECA), an independent body founded by the clubs as a legitimate stakeholder (UEFA 2008; Grant 2009).

\section{FIFPro: Lack of bargaining partners}

FIFPro's record after the transfer system case supports the idea that interest group success in other venues is less probable when veto player status does not suffice but other actors' cooperation is needed. Following Bosman and the transfer system investigation, FIFPro emerged as a legitimate representative of the players backed by the Commission. Since the transfer negotiation, FIFPro has been incorporated by governing bodies to their consultation structures (Holt 2006, p.148-151). Although this was certainly an improvement, FIFPro has not developed a major role within football governing structures and its demands have been relatively modest.

UEFA normalised its relationship with FIFPro and, in 2004, agreed to a tripartite social dialogue by involving the European Professional Football Leagues (EPFL), which UEFA also 
recognised as a legitimate stakeholder (Branco Martins 2004). Then, as recommended by the Independent European Sport Review (Arnaut 2006), UEFA endorsed the European social dialogue (under the Commission's umbrella) as a vehicle for gaining some immunity from European antitrust law. The social dialogue in the professional football sector was launched in July 2008 (European Commission 2008), although UEFA only agreed to that after gaining concessions from the social partners, which proved an obstacle for reaching any agreement within the social dialogue committee (Parrish \& Miettinen 2008, p.110-112).

Whilst the social dialogue represents an opportunity for FIFPro, the outcome has been almost negligible to date. FIFPro officers have expressed their frustration to this respect. This is due to the fact that the social dialogue follows a different institutional logic than competition policy (Parrish \& Miettinen 2008, p.46-49). Whereas the social dialogue delegates legislative powers to the social partners and provides some immunity from competition law, it takes willing and able bargaining partners for it to work (Schäfer \& Streeck 2008). Yet, in football, non-decision and passivity represented a suitable option for clubs and football bodies because they face little incentives for further liberalisation (Meier 2005). Moreover, UEFA opposed a social dialogue taking place outside its committee structure. According to the legal framework of the social dialogue, UEFA, as a governing body, did not qualify as a participant of the social dialogue (Parrish \& Miettinen 2008, p.48-49), for it is neither employer nor employee. Yet, in an attempt to unblock the social dialogue the social partners (FIFPro as employees, ECA and EPFL as employers) accepted UEFA as associate partner to the committee and UEFA president Michel Platini as chairman (European Commission 2008).

\section{UEFA: Adaptation and strategic reorientation}

Whereas G-14 and FIFPro failed to achieve substantial policy change, UEFA used its incumbent's advantage to adapt to the power shifts induced by the EU's involvement in sport (García 2007b, 2009). Outside European competition policy, and in particular among the 
Member States, UEFA had political legitimacy on its side because, for political stakeholders, UEFA represents best the idea that sport is more than a mere economic activity (Dimitrakopoulos 2006). Moreover, UEFA possessed organisational capacities to skilfully align its policy priorities with those of the Member States and a majority within the European parliament (Parrish 2003, García 2007b). As shown, UEFA has much to lose from public and private enforcement of competition law but the multi-institutional nature of the EU, however, opened a line of defence for UEFA, adeptly exploited by gaining political support from the Member States. The logic of private litigation before the courts, however, is different and it is less open to external influences. Thus, it is not surprising that UEFA has looked to develop its interest representation activities in larger political arenas.

As shown, UEFA was able to counter the G-14 challenge, to normalise its relationship with FIFPro and to occupy a central position within the social dialogue despite having to concede some ground to the Commission's liberalising efforts. Moreover, UEFA intensified its efforts to secure economic stability of the professional game. Commission and European Parliament have been quite supportive of these UEFA regulatory efforts (cf. European Parliament 2006; European Commission 2007). Thus, UEFA underwent a process of forced and pragmatic adaptation to the supervisory role of EU institutions (Garcia 2009). UEFA has realised that the role of the sport bodies can best be defended if the European model of sport makes a good case for good governance (García 2007b).

\section{Conclusion}

We have argued that competition policy features an attractive combination of success probabilities and low cost functions that can increase its expected utility for certain interest groups, in particular, when interest groups can align their policy preferences with the liberalising agenda of DG Comp and when they can become veto players through claimant status. However, narrow issue definition and politicisation can limit interest groups' utility 
deriving from public enforcement of competition policy. Moreover, empowerment effects might be hard to transfer. Our case studies support these ideas to some extent even though the collective selling questions the relevance of narrow issue definition since it was mainly G14's hesitant approach that prevented more substantial institutional change.

Without doubt, public enforcement of competition policy has brought some policy shifts favouring clubs and players increasing their share in professional football's revenues. The two cases' outcome in terms of institutional change is debatable, though. It has been claimed that EU involvement in sport opened the possibilities of a transformation of the vertical governance represented by the sporting pyramid (García 2007b). New stakeholders and new governance arrangements in European sport have emerged (European Commission 2007). Thus, European football's governance has evolved towards a more horizontal structure of stakeholder networks (García 2007b, 2009, Holt 2006).

It is safe to affirm that the legitimacy of the governing bodies has been successfully contested by players and club and that EU competition policy has induced some institutional change in European football by challenging the sport bodies' monopoly and legitimising the claims of clubs and players. Accordingly, both interest groups have been incorporated to consultative bodies such as UEFA's Professional Football Strategy Council. FIFPro is engaged within FIFA's dispute resolution chamber. Obviously, football's governing bodies can no longer afford ignoring these stakeholders. Nevertheless, FIFA and UEFA are still the dominant actors in football governance and have been trying to restrict institutional concessions to other stakeholders. Whereas the inclusion of formerly marginalised interest groups represents certainly more than mere 'window dressing' - since these stakeholders can resort to private litigation - given the prospects of far-reaching power shifts offered by European competition policy, these institutional changes appear limited. 
Concerning clubs’ procedural empowerment, ECA chairman Karl-Heinz Rummenigge (2011) has recently complained about difficult cooperation with FIFA and UEFA on issues of player release and announced to return to a more confrontational strategy. Regarding the social dialogue committee established in 2008, Parrish (2011) has correctly argued that this institutional venue has the potential to grant stakeholders a superior status to football's governing bodies. However, the social dialogue's outcomes appear limited so far given the fact that the Commission has been eager to promote collective bargaining within professional football since 2001. Considering that the formal social dialogue has started not until 2008, it seems premature to reach a final conclusion on the future of the formal social dialogue and its impact on football governance since it can be argued that those eager to contest the traditional power of the governing bodies might have expected too much too soon.

Concerning the relevance of football's case for the more general debate on interest group politics in the EU, we have shown that competition policy has to be understood as a venue of interest group politics in its own right. We suggested that EU competition policy increases the probability of success for interest groups interested in the Commission's market liberalisation agenda, while reducing the costs for political action since claimant status (and not legitimacy, representativeness or capacity for collective action) suffices to get access. Yet, narrow issue definition within the arena of competition policy might also limit the feasible benefits from political action. Moreover, the involvement of Member States might limit the liberalising agenda of the Commission. Due to its greater sensitivity to politicisation, public enforcement of competition law might bring about smaller benefits to interest groups than private enforcement by litigation. Thus, private litigation appears to have been more consequential for sectoral governance (Parrish 2011). However, our central ideas on success probabilities and cost-benefit-relations seem also to apply to private enforcement of competition law. Moreover, the case of sport serves also to illustrate that ECJ also responds to political 
criticism. Following complaints about EC law's insensitivity to the specificity of sport, ECJ have developed a highly complex case law approach to sport issues (Arnaut 2006).

Finally, our reasoning that competition policy does not necessarily empower interest groups to succeed in other venues applies to public as well as to private enforcement of competition law. We hypothesized that one, albeit not the exclusive, explanation for the relatively limited empowerment of clubs and players in football governance is that successful action in alternative political venues following a different institutional logic requires further investments in organisational capabilities since claimant status might not suffice.. However, internal heterogeneity of both G-14 and FIFPro also contributed to their lack of effectiveness. Furthermore, the intervention of Member States governments, moving these issues to the high politics agenda, proved difficult to deal with for FIFPro and G-14. Nevertheless, competition policy appears as a venue to be used by interest groups that support a liberalising agenda and have only limited resources. 


\section{References}

Banks, S. (2002) Going down: Football in crisis (London: Mainstream sport).

Bose, M. (2000) Players' rift with FIFA threatens transfer talks, The Daily Telegraph, 28

October 2000,

http://www.telegraph.co.uk/sport/main.jhtml?xml=/sport/2000/10/28/sfnbos28.xml [Accessed 21-2-2007].

Bouwen, P., \& McCown, M. (2007). Lobbying versus litigation, Journal of European Public Policy 14(3), pp. 422-443.

Coen, D. (2007) Empirical and theoretical studies in EU lobbying, Journal of European Public Policy 14(3), pp. 333-345.

Dabscheck, B. (2003) International unionism's competitive edge, Relations IndustrielleIndustrial Relations 58(1), pp. 85-108.

Dimitrakopoulos, D.G. (2006) More than a market?, Government and Opposition 41(4), pp. 561-580.

Downs, A. (1957), An economic theory of democracy (New York: Harper).

European Commission (1996) Sport and free movement, Bosman case: Background situation on the European Court's decision in the Bosman case, European Commission website. http://ec.europa.eu/sport/sport-and/markt/bosman/b_bosman_en.html [Accessed 1-5-2007].

European Commission (1998) Broadcasting of sports events and competition law, Competition Policy Newsletter, June 1998, pp. 18-28. 
European Commission (2000) Football transfers: Commission underlines the prospect of further progress, European Commission Press Release, IP/00/1417, 6 December.

European Commission (2001a) Commission opens proceedings against UEFA's selling of TV rights to UEFA Champions League, European Commission Press Release, IP/01/1043, 20 July.

European Commission (2001b) The UEFA Champions League: Background note, MEMO/01/271, 20 July.

European Commission (2001c) Outcome of discussions between the Commission and FIFA/UEFA on FIFA regulations on international football transfers, European Commission Press Release, IP/01/314, 5 March.

European Commission (2002a) Commission welcomes UEFA's new policy for selling the media rights to the Champions League, European Commission Press Release, IP/02/806, 3 June.

European Commission (2002b) Commission closes investigations into FIFA regulations on international football transfers, European Commission Press Release, IP/02/824, 5 June.

European Commission (2003) Decision relating to a proceeding pursuant to Article 81 of the EC Treaty and Article 53 of the EEA Agreement (Comp/C.2-37.398 Joint Selling of the Commercial Rights of the UEFA Champions League). 2003/778/EC, Official Journal, L 291: 25, 23 July.

European Commission (2007) White paper on sport, COM (2007) 391 final, 11 July.

European Commission (2008) Footballers and employers launch new EU forum for social dialogue, European Commission Press Release, IP/08/1064, 1 July. 
European Council (2000) Declaration on the specific characteristics of sport and its social function in Europe, of which account should be taken in implementing common policies, Presidency Conclusions, Nice European Council, 7-9 December.

European Parliament (2007) Resolution of the European Parliament on the future of professional football in Europe, Rapporteur: Ivo Belet (A6-0036/2007, 29 March 2007).

FIFPro (2001) Joint Press Release of FIFA and FIFPro. 3 September 2001.

García, B. (2007a) From regulation to governance and representation, Entertainment and $\begin{array}{lll}\text { Sports Law } & \text { Journal, }\end{array}$ http://www2.warwick.ac.uk/fac/soc/law/elj/eslj/issues/volume5/number1/garcia [Accessed 20-9-2009].

García, B. (2007b) UEFA and the European Union', Journal of Contemporary European Research, 3(3), pp. 202-223.

García, B. (2008) The European Union and the governance of football, Ph.D. dissertation (Department of Politics, International Relations and European Studies, Loughborough University).

García, B. (2009) The new governance of sport, in: R. Parrish, S. Gardiner \& R. Siekmann (eds.) EU, Sport, Law and Policy: Regulation, Re-Regulation and Representation, pp. 115136 (The Hague: TMC Asser Press).

García, B. and Weatherill, S. (2012 forthcoming) 'Engaging with the EU in order to minimise its impact: sport and the negotiation of the Treaty of Lisbon', Journal of European Public Policy, 19 (2). 
Gardiner, S. \& Welch, R. (2007) The contractual dynamics of team stability versus player mobility, Entertainment and Sports Law Journal, 5(1). http://go.warwick.ac.uk/eslj/issues/volume5/number1/gardiner_welch. [Accessed 20-09-2009]

Grant, W. (2009) The representation of football in the European Union, in: S. Gardiner, R. Parrish, and R. Siekmann (eds.) EU, Sport, Law and Policy: Regulation, Re-regulation and Representation, , pp. 401-415 (The Hague: T.M.C. Asser Press).

Goodbody, J. (1996) Foreigners ruling scrapped by UEFA, The Times, 20 February 1996.

Holt, M. (2006) UEFA, governance and the control of club competition in European football, (London: Football Governance Research Centre, Birbeck University of London).

Majone, G. (1997) From the positive to the regulatory state, Journal of Public Policy, 17(1), pp. 139-167.

Meier, H.E. (2005) Die politische Regulierung des Profifußballs (Köln: Sport and Buch Strauß).

Meier, H.E. (2009) Emergence, dynamics and impact of European sport policy, in: S. Gardiner, R. Parrish, and R. Siekmann (eds.) EU, Sport, Law and Policy: Regulation, Reregulation and Representation, pp. 7-34 (The Hague: T.M.C. Asser Press).

Moorhouse, H.F. (1999) The economic effects of the traditional transfer system in European professional football, Football Studies, 2(1), pp. 90-105.

Moorhouse, H.F. (2007) Financial expertise, authority and power in the European football “industry”, Journal of Contemporary European Research, 3(3), pp. 290-299. 
Parrish, R. (2003) Sports Law and Policy in the European Union (Manchester: Manchester University Press).

Parrish, R., \& Miettinen, S. (2008). The Sporting Exception in European Union Law (The Hague: T.M.C. Asser Press).

Parrish, R., Garcia, B., Miettinen, S, and Siekmann, R. (2010) The Lisbon Treaty and EU Sports Policy, Brussels: European Parliament, PE 438.607.

Pons, J.-F. (1999) Sport and European competition policy: contribution to the twenty-sixth annual conference on international antitrust law and policy, New York, 14-15 October 1999 (Brussels: European Commission).

Pons, J.-F. (2002) La politique européenne de concurence et le sport, Revue du Droit de l'Union Européenne, 2, pp. 241-259.

Prime Minister’s Office (2000) Joint statement by the Prime Minister the Right Honourable Tony Blair MP and Chancellor Gerhard Schroeder, 9 September. http://www.pm.gov.uk/output/Page2855.asp [Accessed 2-11-2009].

Prime Minister's Office (2001) Joint statement by the Prime Minister and Chancellor Gerhard Schroeder, 30 January. http://www.pm.gov.uk/output/Page2653.asp [Accessed 2-112009].

Princen, S., \& Kerremans, B. (2008) Opportunity structures in the EU multi-level system, West European Politics 31(6),pp 1129-1146.

Princen, S., \& Rhinard, M. (2006) Crashing and creeping: agenda-setting dynamics in the European Union, Journal of European Public Policy, 13(7), pp. 1119-1132. 
Reding, V. (2000) Commission's investigation into FIFA's transfer rules: statement to European Parliament, Strasbourg 7 September 2000, Speech/00/290.

Rubin, P.H., Curran, C. \& Curran, J.F. (2001) Litigation versus legislation, Public Choice, 107(3-4), pp. 295-310.

Schäfer, A., \& Streeck, W. (2008) Korporatismus in der Europäischen Union, in: M. Höpner \& A. Schäfer (eds.) Die Politische Ökonomie der europäischen Integration, pp. 203-40 (Frankfurt am Main: Campus).

Tomlinson, A. (1983) 'Tuck up Tight Lads: Structures of Control within Football Culture', in A. Tomlinson (Ed) Explorations in Football Culture. Eastbourne: Leisure Studies Association Publications, pp. 165-186

Tokarski, W., Steinbach, D., Petry, K. \& Jesse, B. (2004) Two Players One Goal? Sport in the European Union (Oxford: Meyer and Meyer Sport).

Tsebelis, G. (2002) Veto Players: How Political Institutions Work. Princeton, NJ: Princeton University Press.

UEFA (2000a) UEFA comment on transfer speculation, Media Release, 176, 1 September.

UEFA (2000b) Football pledges new dialogue on transfers, Media Release, 179, 6 September.

UEFA (2001) UEFA Champions League: A solidarity system for European football (Nyon: UEFA).

UEFA (2002) TV rights agreement: European Commission and UEFA, 6 June. http://www.uefa.com/newsfiles/25624.pdf [Accessed 20-10-2009]. 
UEFA (2006) Review given full backing, UEFA.com, 20 October, http://www.uefa.com/uefa/Keytopics/kind=64/newsId=470475.html [Accessed 1-11-2006].

UEFA (2007) Regulations of the UEFA Champions League 2007/2008. (Nyon: UEFA).

UEFA (2008) Victory for football as a whole: historic meeting between FIFA, UEFA and several top European clubs, Media Release, 4, 15 January. http://www.uefa.com/newsfiles/646362.pdf [Accessed 21-1-2008]

Ungerer, H. (2003) Competition policy and the issue of access in broadcasting markets (Brussels: European Commission).

Van den Brink, J.P. (2000) EC competition law and the regulation of football, European Competition Law Review, 21(8), pp. 359-368.

Weatherill, S. (2003) Fair play, please!, Common Market Law Review 40(1): 51-93.

Weatherill, S. (2010) 'Fairness, openness and the specific nature of sport: does the Lisbon Treaty change EU sports law?', International Sports Law Journal 2010/3-4: 1-6.

Wilks, S. (2005) Competition policy, in: H. Wallace, W. Wallace \& M.A. Pollack (eds.) Policy Making in the European Union, 5th ed., pp. 113-139 (Oxford: Oxford University Press).

Wilks, S., \& Bartle, I. (2002) The unanticipated consequences of creating independent competition agencies, West European Politics, 25(1), pp. 148-172.

Woll, C. (2006) Lobbying in the European Union, Journal of European Public Policy, 13(3), pp. 456-469. 